\title{
Definitions and pathophysiology of vasoplegic shock
}

\author{
Simon Lambden ${ }^{1,2}$, Ben C. Creagh-Brown ${ }^{3,4^{*}}$ (D) Julie Hunt ${ }^{4}$, Charlotte Summers ${ }^{1,2}$ and Lui G. Forni $i^{3,4}$
}

\begin{abstract}
Vasoplegia is the syndrome of pathological low systemic vascular resistance, the dominant clinical feature of which is reduced blood pressure in the presence of a normal or raised cardiac output. The vasoplegic syndrome is encountered in many clinical scenarios, including septic shock, post-cardiac bypass and after surgery, burns and trauma, but despite this, uniform clinical definitions are lacking, which renders translational research in this area challenging. We discuss the role of vasoplegia in these contexts and the criteria that are used to describe it are discussed. Intrinsic processes which may drive vasoplegia, such as nitric oxide, prostanoids, endothelin-1, hydrogen sulphide and reactive oxygen species production, are reviewed and potential for therapeutic intervention explored. Extrinsic drivers, including those mediated by glucocorticoid, catecholamine and vasopressin responsiveness of the blood vessels, are also discussed. The optimum balance between maintaining adequate systemic vascular resistance against the potentially deleterious effects of treatment with catecholamines is as yet unclear, but development of novel vasoactive agents may facilitate greater understanding of the role of the differing pathways in the development of vasoplegia. In turn, this may provide insights into the best way to care for patients with this common, multifactorial condition.
\end{abstract}

Keywords: Vasoplegia, Shock

\section{Background}

Vasoplegia is an abnormally low systemic vascular resistance (SVR) that is manifest as profound hypotension or the requirement for therapies to avoid this, in the presence of a normal or increased cardiac output (Fig. 1). Physiologically, a low SVR is defined as a low ratio of difference in blood pressure between arterial (MAP) and venous pressures (RAP) to the cardiac output [SVR $=(\mathrm{MAP}-\mathrm{RAP}) / \mathrm{CO}]$. Clinically, vasoplegia is often recognised in the absence of such comprehensive haemodynamic data. The causes of vasoplegia are diverse, and several definitions have been described for specific causes; similarly, related terminologies are variably used. The absence of consensus clinically based definitions of vasoplegia impede progress in understanding the pathophysiology of vasoplegia; this is particularly true when considering the similarities between vasodilatory

\footnotetext{
* Correspondence: bencb@nhs.net

${ }^{3}$ Surrey Perioperative Anaesthetic Critical care collaborative group (SPACeR) Intensive Care, Royal Surrey County Hospital NHS Foundation Trust, Guildford, UK

${ }^{4}$ Department of Clinical and Experimental Medicine, Faculty of Health and Medical Sciences, University of Surrey, Guildford, UK

Full list of author information is available at the end of the article
}

shock due to sterile or non-sterile causes-for example hypotension despite adequate fluid resuscitation in early burns injury versus early sepsis.

Patients in hospitals most commonly experience hypotension due to vasodilatation because of the administration of general or neuraxial anaesthesia, and even when transient this has been associated with adverse outcomes [1-3]; however, further discussion is beyond the scope of this review. Similarly, hypotension due to vasodilatation resulting from neurogenic shock has a discrete pathophysiology (loss of sympathetic innervation due to spinal cord injury) and is not considered further. This review focuses on the causes of vasoplegia that reflect a varied response to pathogen-associated molecular patterns (PAMPS) and damage-associated molecular patterns (DAMPS) (Fig. 2). The response to these stimuli generates a combination of vasodilatation and increased capillary permeability. Capillary leak, coupled with greater vessel capacitance mediated by vasoplegia may result in absolute, or more commonly relative, hypovolemia. Fluid resuscitation to treat this phenomenon is a standard of care, but

(c) The Author(s). 2018 Open Access This article is distributed under the terms of the Creative Commons Attribution 4.0 International License (http://creativecommons.org/licenses/by/4.0/), which permits unrestricted use, distribution, and 


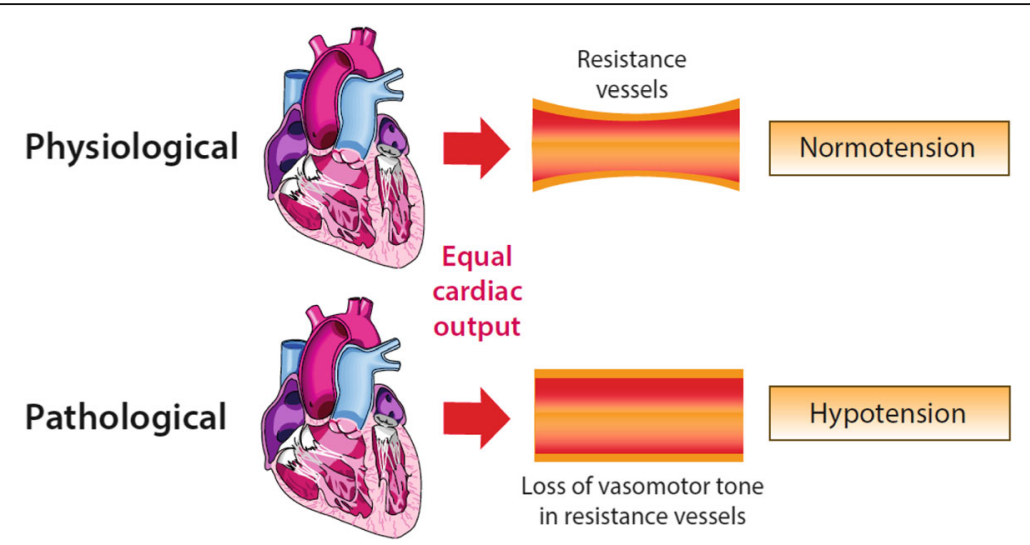

Fig. 1 The relationship between tone in resistance vessels, under conditions of equal cardiac output, and the systemic blood pressure-preserved vasomotor tone leading to normotension and loss of vasomotor tone leading to hypotension

this does not treat the underlying pathology and positive fluid balance is associated with harm [4].

It is uncertain if it is justifiable to consider vasoplegia to be a pathophysiologically distinct entity representing uncontrolled failure of vascular homeostasis or to represent the end of a spectrum of vasodilatation.

Vasoplegic shock (VS), synonymous with distributive shock, is a more significant circulatory perturbation that is best described as vasoplegia with evidence of tissue hypoperfusion which may be accompanied with hyperlactataemia [5]. The presence of a raised lactate portends a particularly grave prognosis in the presence of shock or indeed septic shock $[6,7]$. This review describes the key mechanisms involved in the development of VS, a process that is mediated by a diverse set of pathways which combine and contribute to the evolution of the shock state. Advancing our understanding of these pathways and their role in the transition from adaptive physiological to maladaptive pathological response may provide novel diagnostic tools, prognostic insights and therapeutic targets to guide the management of vasoplegia.

To date, our treatment options are limited and do not target some of the main pathophysiological pathways. First-line vasopressor therapy is typically with catecholamines and

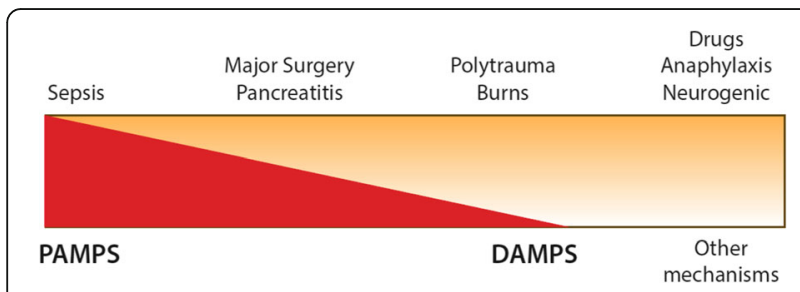

Fig. 2 The main clinical causes of vasoplegia (top) and how they are perceived to relate to underlying aetiologies (bottom)-i.e. sepsis is predominantly a response to PAMPS (pathogen-associated molecular patterns) compared to burns or polytrauma where DAMPS (damage-associated molecular patterns) are the major cause resistance is referred to as catecholamine-resistant hypotension (CRH). Although vasopressor infusion is required in order to maintain an adequate MAP, significant variation remains in clinical practice, particularly with regard to personalised targets depending on premorbid characteristics, and current research efforts are addressing this issue [8]. Moreover, it is well recognised that infused catecholamines are associated with a range of adverse effects on the metabolic, immune and coagulation systems $[9,10]$.

The tools available to clinicians to monitor the severity and impact of vasoplegia are limited [11, 12] and existing treatment goals may not result in the desired tissue level effects on microvascular flow [13]. Improved understanding of the pathophysiology of vasoplegia combined with new tools to monitor the impact of interventions on vessel function may lead to the development of the next generation of vasoactive therapies. The measurement of cardiac output, systemic blood pressure and central venous pressure allow derivation of the SVR, although targeting 'normal' values with insufficient consideration of their components may be hazardous [13].

\section{Causes of vasoplegia \\ Sepsis}

The commonest cause of vasoplegia in critical care is sepsis. The incidence is dependent upon the definition used and the patient population under consideration [14]. Receipt of vasopressors, where appropriate, is now recognised as a cardinal feature of septic shock and indeed the most recent definition of septic shock does not require the presence of persistent hypotension. However, it includes administration of vasopressors to maintain a mean arterial pressure (MAP) of $65 \mathrm{mmHg}$ (in the absence of hypovolaemia) and an elevated blood lactate level [15] in the presence of sepsis. This contrasts with earlier definitions which required hypotension as 
reflected by a low MAP $(<60 \mathrm{mmHg})$ in the absence of hypovolaemia and other cause of hypotension [16].

\section{Cardiac surgery}

Vasoplegia and VS occurring in patients following cardiac surgery are the second commonest cause. Diagnosis is more complex as there is an ever-present risk of impaired cardiac output contributing to hypotension, the cause of which must be ascertained early-differentiating between reduced preload from bleeding, impaired myocardial contractility or the occurrence of cardiac tamponade. The second main complicating factor is the frequent use of vasodilatory inotropes that directly influence vascular tone. Therefore, although no consensus definition exists, there are several working definitions that combine i) hypotension in the absence of a low cardiac output state and ii) absence of infection; additional criteria may also include the absence of vasodilatory inotropes such as dobutamine or milrinone, or presence of evidence of tissue hypoperfusion. Clinical factors that predispose to the development of vasoplegia following cardiac surgery have been described [17-19] and various treatment regimens considered, including the use of alternative vasoconstrictors [20-22]. Although vasoplegia following cardiac surgery is often attributed to exposure to an extracorporeal circuit the evidence in support of this remains mixed [23].

\section{Non-cardiac surgery}

Hypotension due to vasodilatation in patients following major non-cardiac surgery is usually manifest as requirement for vasopressors to maintain an adequate MAP following appropriate resuscitation to restore euvolaemia, and its incidence is seldom reported. Reported risk factors include prolonged surgery and significant requirement for blood transfusion [24, 25]. Where postoperative admission to a critical care environment is routine, the use of vasopressors in the postoperative period to support blood pressure following optimisation of fluid status is commonplace. Although vasopressors may be required to counteract the systemic vasodilatory effects of neuraxial blockade, such as epidural analgesia, where requirements are significant in an adequately resuscitated patient then this should be considered to be vasoplegia.

\section{Burns, trauma and pancreatitis}

These are conditions united by significant tissue injury, with consequent hypermetabolism, systemic inflammation and predisposition to developing organ dysfunction. Vasoplegia could be considered to be one such organ dysfunction, and is a recognised complication of polytrauma, burns [26-28] and, even in the absence of infection, severe pancreatitis-where vasoplegia is associated with adverse outcome $[29,30]$.

\section{The pathophysiology of vasoplegia Normal physiology}

SVR is determined by changes in arteriolar diameter, controlled by the contractile activity of the vascular smooth muscle cells (VSMC) in the tunica media. The contractile state of the VSMC is referred to as the vascular 'tone' and is regulated through intracellular calcium $\left(\mathrm{Ca}^{2+}\right)$ concentration. VSMC contraction is driven by a rise in cytosolic $\mathrm{Ca}^{2+}$ concentration through release of stored $\mathrm{Ca}^{2+}$ from the sarcoplasmic reticulum as well as extracellular $\mathrm{Ca}^{2+}$ influx through voltage-sensitive channels. Relaxation of the VSMC is driven by a fall in cytosolic $\mathrm{Ca}^{2+}$, due to uptake of $\mathrm{Ca}^{2+}$ by the sarcoplasmic reticulum and expulsion of potassium $\left(\mathrm{K}^{+}\right)$or $\mathrm{Ca}^{2+}$ (via $\mathrm{K}^{+}$channels and $\mathrm{Ca}^{2+}$-ATPase pumps) into the extracellular space, resulting in cellular hyperpolarisation and vasodilation. Vascular tone is therefore dependent on the rate of $\mathrm{Ca}^{2+}$ influx versus removal, which in turn is regulated by intrinsic and extrinsic mechanisms [31]. Intrinsic regulators include:

i. endothelial secretions (nitric oxide, prostacyclin, endothelin)

ii. vasoactive metabolites (acidosis, hypoxia, hydrogen peroxide)

iii. autacoids (serotonin, prostaglandins, thromboxane $A_{2}$ )

Extrinsic regulation is largely mediated by sympathetic neural control and vasoactive hormones, which include adrenaline, angiotensin II and vasopressin.

\section{The pathophysiology of vasoplegia: intrinsic regulators Nitric oxide}

Nitric oxide (NO), first identified as the endothelial-derived relaxing factor (EDRF) [32], is a critical regulator of vascular function in both health and disease. NO diffuses freely from the endothelium into the neighbouring VSMC and bloodstream causing vasodilation, inhibition of VSMC proliferation, platelet activation and leukocyte adhesion. It is generated from L-arginine by endothelial nitric oxide synthase [33], and to a lesser extent neuronal nitric oxide synthase [34] (eNOS and nNOS, respectively). These calcium-dependent constitutive isoforms produce NO in picomolar concentrations and this induces cGMP-PKG-mediated vasodilation [35-37]. Inflammatory autacoids, including bradykinin and thrombin, increase NO production and vasodilation by activating eNOS. In addition, inflammatory cytokines and PAMPs such as lipopolysaccharide (LPS) induce the synthesis of the third calcium-independent, inducible NOS isoform (iNOS). This results in an increase in NO of two to three orders of magnitude above baseline and is a major driver of acute vascular dysfunction in shock [38]. Administration of non-selective inhibitors of NOS has been shown to be associated with improvement in 
haemodynamics in patients with septic shock but also, despite this, increased mortality-probably through the impact of NOS inhibition on immune cell and cardiac NO production $[39,40]$. Therapies that target the vasculature and regulate, but not entirely abolish, the increase in NO synthesis may offer a more favourable profile to those previously tested to-date in clinical trials [41].

\section{Prostanoids}

Prostacyclin $\left(\mathrm{PGI}_{2}\right)$ is produced by the endothelium constitutively and causes platelet aggregation [42] and induces cAMP-PKA-mediated vasodilation [43, 44]. Prostacyclin production is greatly increased in inflammation and contributes to vasodilation. A broad range of inflammatory stressors and/or PAMPs, including interleukin 1(IL-1), tumour necrosis factor $\alpha$ (TNF- $\alpha$ ), hypoxia and LPS, provoke the induction of COX-2 isoform and increased synthesis of $\mathrm{PGI}_{2}$ by prostacyclin synthase (PGIS) [45-47], which drives vasoplegia. Therapeutic trials of nonselective COX inhibition in sepsis proved inconclusive, with any beneficial effects on the degree of vasoplegia mediated by $\mathrm{PGI}_{2}$ likely offset by other prostaglandin-mediated actions [48].

A short lived prostainoid, thromboxane A2 $\left(\mathrm{TXA}_{2}\right)$ opposes the actions of $\mathrm{PGI}_{2}$ and promotes vasoconstriction and platelet aggregation [49]. Therefore $\mathrm{TXA}_{2}$ has been implicated as a potential causative factor in the increased risk of cardiac ischaemia in patients taking COX2 inhibitors [50]. $\mathrm{TXA}_{2}$ regulates vascular tone through binding to thromboxane-prostanoid (TP) receptors in vascular smooth muscle and, in keeping with other agents, promotes calcium influx and vascoconstriction [51]. Animal studies have suggested that knockout of the TP receptor is associated with reduced iNOS expression and protection against vascular hyporesponsiveness, suggesting a role for $\mathrm{TXA}_{2}$ as a regulator of vasoplegia $[52,53]$. In humans, limited evidence suggests that the balance between $\mathrm{TXA}_{2}$ and $\mathrm{PGI}_{2}$ may be important with high relative levels of $\mathrm{TXA}_{2}$ associated with worse outcome in a preliminary study of patients with sepsis [54].

\section{Endothelin 1}

Endothelin 1 (ET1) is the predominant isoform of the endothelin family and is a small peptide which acts as a vasoconstrictor [55]. ET1 activates endothelin A (ETA) receptors in the VSMC, which again drive the elevation of intracellular $\mathrm{Ca}^{2+}$ and contraction [56]. Subtypes of endothelin B (ETB) receptors, found in the endothelium and vascular smooth muscle, act as an autoregulatory mechanism for controlling basal tone through vasodilatation and smooth muscle contraction [57]. In conditions of inflammatory stress, however, ET1 has potentially deleterious effects through the activation of a number of signalling pathways, increasing synthesis of IL-1, TNF-a and IL-6 [58]. Selective and non-selective blockade of the ET receptor subtypes have been shown to have promise in a range of animal models [59].

\section{Oxygen free radicals}

Uncoupling of endothelial NOS enzymes may cause an increase in reactive oxygen species and mitochondrial dysfunction [33]. The superoxide anion may reduce NO to form peroxynitrite $\left(\mathrm{ONOO}^{-}\right)$, which acts as a powerful oxidising agent that provokes cellular dysfunction and vasoplegia [60]. Under physiological conditions, the superoxide radical anion is metabolised by superoxide dismutase (SOD). Non-enzymatic mechanisms for superoxide metabolism are mediated by ascorbic acid and uric acid. In shock states, excess NO production results in excess $\mathrm{ONOO}^{-}$production, which may be attenuated by antioxidants [61], and reactive oxygen species (ROS) may also cause the deactivation of catecholamines, a phenomenon that can be reversed by the administration of a synthetic mimic of superoxide dismutase [62].

\section{Hydrogen sulphide}

Hydrogen sulphide $\left(\mathrm{H}_{2} \mathrm{~S}\right)$ is synthesised from the amino acid L-cysteine through vitamin B6-dependent cystathionine- $\beta$-synthase or cystathionine- $\gamma$-lyase [63]. $\mathrm{H}_{2} \mathrm{~S}$ readily diffuses into the vascular smooth muscle and at low concentrations may have cytoprotective effects, although in sepsis concentrations are significantly elevated [64]. At higher concentrations, $\mathrm{H}_{2} \mathrm{~S}$ contributes to the development of vasodilatory shock through a range of oxygen-dependent actions, including inhibition of cytochrome c oxidase with impairment of mitochondrial function, activation of potassium ATP channels and inhibition of endothelial angiotensin converting enzyme activity [63, 65-67]. In addition, $\mathrm{H}_{2} \mathrm{~S}$ interacts with NO, which may attenuate NO actions $[68,69]$. $\mathrm{H}_{2} \mathrm{~S}$ has also been suggested as a potential therapeutic agent leading to the development of a cytoprotective hibernation-like state. Animals treated with $\mathrm{H}_{2} \mathrm{~S}$ are protected from both lethal hypoxia [70] and haemorrhage [71]. This finding has led to the pre-clinical study of $\mathrm{H}_{2} \mathrm{~S}$ treatment in modulating the deleterious effects of ischaemia-reperfusion injury in experimental models, including porcine myocardial injury [72].

\section{Non-endothelial: potassium channel hyperpolarisation}

As indicated, efflux of potassium through ATP-sensitive potassium channels is an important mechanism for the regulation of VSMC membrane potential. Over-activation of potassium channels results in hyperpolarization of the cell, with resulting inactivation of voltage-gated calcium channels. The subsequent vasodilatation is an important driver of vascular dysfunction. In addition to endothelial-derived 
mediators, a number of circulating factors can drive potassium channel-mediated vascular dysfunction, including hypoxia [73], reduced $\mathrm{pH}$ [74] and increased circulating lactate [75]. The vascular dysfunction induced by inflammatory stress such as endotoxin [76] led to the hypothesis that inhibition of potassium channels may offer a novel therapeutic strategy. Animal models showed haemodynamic improvements following inhibition with the specific ATP-sensitive potassium channel blocker glibenclamide [77]. However, phase 2 randomised controlled trials in human subjects demonstrated no benefit [78], and concerns regarding non-vascular effects limit its potential utility [79].

\section{The pathophysiology of vasoplegia: extrinsic regulators Catecholamine resistance}

The development of vasoplegia may also be driven by changes in the efficacy of circulating catecholamines in generating VSMC contraction. Animal models suggest that in later stages of sepsis, alpha-1 adrenoceptor expression falls, resulting in peripheral resistance to norepinephrine [80, 81]. In human studies, the expression of peripheral receptors appears to be related to illness severity, with increased expression in mild disease and reduced expression observed in severe sepsis, suggesting that in patients with vasoplegia, a similar pattern to that observed in rodent models may occur [82].

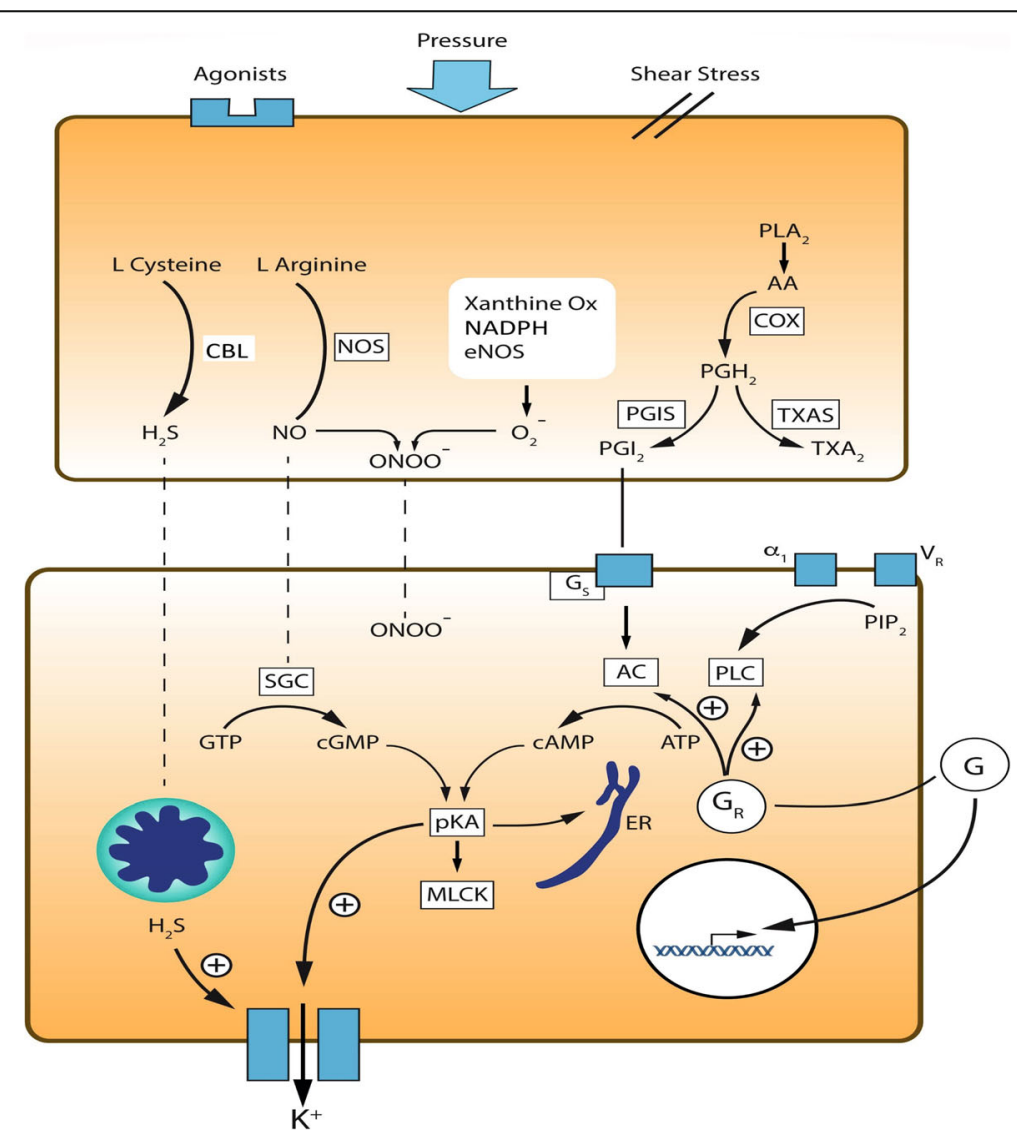

Fig. 3 Endothelial and smooth muscle-mediated mechanisms of vascular dysfunction in shock. Hormonal and mechanical factors drive endothelial cell activation in the vasculature. Increased expression of the inducible isoform of nitric oxide synthase (iNOS) generates increased production of nitric oxide (NO) from arginine. NO directly reduces vascular tone through the activation of soluble guanylate cyclase, which catalyses the conversion of GTP to cyclic GMP. In addition, $\mathrm{NO}$ combines with oxygen free radicals $\left(\mathrm{O}_{2}^{-}\right)$produced by dyfunctional mitochondria and a number of enzymes, including endothelial nitric oxide synthase (eNOS), NADPH and xanthine oxidase. The synthesised peroxynitrite also directly contributes to smooth muscle relaxation. Hydrogen sulphide $\left(\mathrm{H}_{2} \mathrm{~S}\right)$ is synthesised from L-cysteine by cystathionine- $\beta$-synthase or cystathionine- $\gamma$-lyase $(\mathrm{CBL})$. In shock, $\mathrm{H}_{2} \mathrm{~S}$ reduces vascular tone through inhibition of mitochondrial function and activation of potassium channels. Arachidonic acid is converted to vasoactive prostaglandins via a two-step pathway involving cyclooxygenase (COX) isoforms and prostacyclin synthase $(P G / S)$, which synthesises prostacyclin $(P G / 2)$. This in turn drives vasodilatation via the activation of stimulatory G-protein-coupled receptors (Gs), which promotes synthesis of cyclic AMP (AMP) from ATP by adenylate cyclase (AC). Thrombxane A2 (TXA2) is synthesised from the common intermediate $\mathrm{PGH}_{2}$ and plays a role in the regulation of vascular tone in shock states. In the smooth muscle, activation of protein kinase A (PKA) by a number of routes drives smooth muscle relaxation through potassium channel- and endoplasmic reticulum (ER)-mediated hyperpolarization and activation of myosin light chain kinase (MLCK). Glucogorticoids (G) activate glucocorticoid receptors (GR) through both classic and non-classic mechanisms to regulate vascular tone, a process that is impaired in a number of ways in shock. Changes in expression of adrenergic $\left(a_{1}\right)$ and vasopressin $\left(V_{R}\right)$ receptors and their circulating agonists impair the function of vascular smooth muscle in shock states 


\section{Corticosteroid response}

Glucocorticoids drive diverse tissue responses in inflammation, including circulating immune cell function and cytokine release [83]. These processes are driven by regulation of a number of intermediate pathways, including inducible NOS-mediated NO synthesis and COX2 activity [84]. In the vasculature, steroid receptors are present in both endothelial and vascular smooth muscle and, under physiological conditions, potentiate the response to circulating catecholamines and angiotensin II $[85,86]$. In addition, the rapid cellular actions of steroids can promote increased concentrations of second messengers such as inositol-3-phosphate and cAMP $[87,88]$. Limited evidence suggests that critical illness-related corticosteroid insufficiency may develop in shock states. Causes of this insufficiency include relative insufficiency of the HPA axis [89], adrenal failure [90] or necrosis [91], and in some cases peripheral resistance to corticosteroids [90]. These factors may combine to exacerbate vascular dysfunction in shock and provide a mechanism for the proposed benefit of exogenous steroid administration to reduce the severity or duration of vasopressor dependence in septic shock [92-94].

\section{Endogenous vasopressin}

Vasopressin acts via specific V1 receptors on the VSMC surface to promote increased intracellular calcium via $G$ protein-coupled receptors and phospholipase $C$, which in turn drives contraction. In septic shock, plasma concentrations of vasopressin increase in the early stages of shock; however, after $24 \mathrm{~h}$ levels fall to sub-normal levels, which may be a mechanism for loss of vascular tone [95]. This may be associated with a reduction in peripheral receptor numbers, a phenomenon observed in animal models [81]. In addition, $\mathrm{V} 2$ receptors on endothelial cells may provoke vasodilatation via the increased synthesis of NO [96].

\section{Conclusions}

Although vasoplegia is a well-recognised phenomenon, it still suffers from the lack of a unifying clinical definition. This prevents clinical trialists and translational scientists from sharing the common language necessary to facilitate research and increase understanding of this phenomenon. Certainly, we believe that a uniform approach to describing vasoplegia would reap benefits and stimulate further investigation of the underlying pathophysiological mechanisms. Vasoplegia is a complex phenomenon centred around vascular reactivity with multiple contributory potential mechanisms (outlined in Fig. 3). The advent of further alternatives to catecholamines, such as angiotensin II [97], may herald a new approach to treatment and the potential for alternative approaches-for further details, the reader is invited to consult the treatment article published in the same series.
Optimum targets for systemic blood pressure remain contentious, and increasingly and appropriately, the pharmacological agents used to achieve these goals will be more closely scrutinised.

\section{Abbreviations}

CO: Cardiac output; $\mathrm{CRH}$ : Catecholamine-resistant hypotension; DAMPS: Damage-associated molecular patterns; MAP: Mean arterial pressure; MLCK: Myosin light chain kinase; PAMPS: Pathogen-associated molecular patterns; RAP: Right atrial pressure; ROS: Reactive oxygen species; SVR: Systemic vascular resistance; VS: Vasoplegic shock; VSMC: Vascular smooth muscle cells

\section{Acknowledgements}

The authors would like to acknowledge Mr. Philip Ball (University of Cambridge) for his assistance in preparing the images used in this review.

Funding

$\mathrm{SL}$ is an NIHR Clinical Lecturer in Intensive Care Medicine.

Authors' contributions

All authors (SL, BCCB, JH, CS and LGF) contributed to the development of the manuscript and read and approved the final manuscript.

Ethics approval and consent to participate

Not applicable.

Consent for publication

Not applicable.

Competing interests

The authors declare that they have no competing interests.

\section{Publisher's Note}

Springer Nature remains neutral with regard to jurisdictional claims in published maps and institutional affiliations.

\section{Author details}

${ }^{1}$ University of Cambridge, Cambridge, UK. ${ }^{2}$ Cambridge University Hospitals NHS Foundation Trust, Cambridge, UK. ${ }^{3}$ Surrey Perioperative Anaesthetic Critical care collaborative group (SPACeR), Intensive Care, Royal Surrey County Hospital NHS Foundation Trust, Guildford, UK. ${ }^{4}$ Department of Clinical and Experimental Medicine, Faculty of Health and Medical Sciences, University of Surrey, Guildford, UK.

Received: 22 January 2018 Accepted: 19 June 2018

Published online: 06 July 2018

References

1. Bijker JB, van Klei WA, Kappen TH, van Wolfswinkel L, Moons KG, Kalkman CJ. Incidence of intraoperative hypotension as a function of the chosen DefinitionLiterature definitions applied to a retrospective cohort using automated data collection. J Am Soc Anesthesiol. 2007;107(2):213-20.

2. Walsh M, Devereaux PJ, Garg AX, Kurz A, Turan A, Rodseth RN, Cywinski J, Thabane L, Sessler DI. Relationship between intraoperative mean arterial pressure and clinical outcomes after noncardiac SurgeryToward an empirical definition of hypotension. Anesthesiology. 2013;119(3):507-15.

3. Futier $E$, Lefrant J-Y, Guinot P-G, Godet T, Lorne E, Cuvillon P, Bertran S, Leone M, Pastene B, Piriou V. Effect of individualized vs standard blood pressure management strategies on postoperative organ dysfunction among high-risk patients undergoing major surgery: a randomized clinical trial. JAMA. 2017:318(14):1346-57.

4. Malbrain ML, Marik PE, Witters I, Cordemans C, Kirkpatrick AW, Roberts DJ, Van Regenmortel N. Fluid overload, de-resuscitation, and outcomes in critically ill or injured patients: a systematic review with suggestions for clinical practice. Anaesthesiol Intensive Ther. 2014;46(5):361-80.

5. Vincent J-L, De Backer D. Circulatory shock. N Engl J Med. 2013;369(18):1726-34.

6. Sterling SA, Puskarich MA, Shapiro NI, Trzeciak S, Kline JA, Summers RL, Jones AE. Characteristics and outcomes of patients with vasoplegic versus tissue dysoxic septic shock. Shock. 2013;40(1):11. 
7. Hernández G, Machado F, Ospina-Tascón G. Defining septic shock. JAMA. 2016;316(4):454-5.

8. The 65 trial. http://www.isrctn.com/ISRCTNISRCTN10580502. Accessed 02 July 2018

9. Singer M. Catecholamine treatment for shock-equally good or bad? Lancet. 2007:370(9588):636-7.

10. Andreis DT, Singer M. Catecholamines for inflammatory shock: a Jekyll-andHyde conundrum. Intensive Care Med. 2016;42(9):1387-97.

11. Cecconi M, De Backer D, Antonelli M, Beale R, Bakker J, Hofer C, Jaeschke R, Mebazaa A, Pinsky MR, Teboul JL. Consensus on circulatory shock and hemodynamic monitoring. Task force of the European Society of Intensive Care Medicine. Intensive Care Med. 2014;40(12):1795-815.

12. Hiemstra B, Eck RJ, Keus F, van der Horst IC. Clinical examination for diagnosing circulatory shock. Curr Opin Crit Care. 2017;23(4):293.

13. Leone M, Asfar P, Radermacher P, Vincent JL, Martin C. Optimizing mean arterial pressure in septic shock: a critical reappraisal of the literature. Crit Care. 2015:19:101.

14. Gaieski DF, Edwards JM, Kallan MJ, Carr BG. Benchmarking the incidence and mortality of severe sepsis in the United States. Crit Care Med. 2013; 41(5):1167-74

15. Singer M, Deutschman CS, Seymour CW, Shankar-Hari M, Annane D, Bauer M, Bellomo R, Bernard GR, Chiche JD, Coopersmith CM, et al. The third international consensus definitions for Sepsis and septic shock (Sepsis-3). JAMA. 2016;315(8):801-10.

16. Levy MM, Fink MP, Marshall JC, Abraham E, Angus D, Cook D, Cohen J, Opal SM, Vincent JL, Ramsay G, et al. 2001 SCCM/ESICM/ACCP/ATS/SIS international Sepsis definitions conference. Intensive Care Med. 2003;29(4):530-8.

17. Mekontso-Dessap A, Houel R, Soustelle C, Kirsch M, Thebert D, Loisance DY Risk factors for post-cardiopulmonary bypass vasoplegia in patients with preserved left ventricular function. Ann Thorac Surg. 2001;71(5):1428-32.

18. Tuman KJ, McCarthy RJ, O'connor CJ, Holm WE, Ivankovich AD. Angiotensinconverting enzyme inhibitors increase vasoconstrictor requirements after cardiopulmonary bypass. Anesth Analg. 1995;80(3):473-9.

19. Carrel T, Englberger L, Mohacsi P, Neidhart P, Schmidli J. Low systemic vascular resistance after cardiopulmonary bypass: incidence, etiology, and clinical importance. J Card Surg. 2000;15(5):347-53.

20. Papadopoulos G, Sintou E, Siminelakis S, Koletsis E, Baikoussis NG, Apostolakis E. Perioperative infusion of low- dose of vasopressin for prevention and management of vasodilatory vasoplegic syndrome in patients undergoing coronary artery bypass grafting-a double-blind randomized study. J Cardiothorac Surg. 2010;5(1):17.

21. Özal E, Kuralay E, Yildirim V, Kilic S, Bolcal C, Kücükarslan N, Günay C, Demirkilic U, Tatar $\mathrm{H}$. Preoperative methylene blue administration in patients at high risk for vasoplegic syndrome during cardiac surgery. Ann Thorac Surg. 2005;79(5):1615-9.

22. Hajjar LA, Vincent JL, Galas FRBG, Rhodes A, Landoni G, Osawa EA, Melo RR, Sundin MR, Grande SM, Gaiotto FA. Vasopressin versus norepinephrine in patients with Vasoplegic shock after cardiac SurgeryThe VANCS randomized controlled trial. Anesthesiology. 2017;126(1):85-93.

23. Sun X, Zhang L, Hill PC, Lowery R, Lee AT, Molyneaux RE, Corso PJ, Boyce $S W$. Is incidence of postoperative vasoplegic syndrome different between off-pump and on-pump coronary artery bypass grafting surgery? Eur J Cardiothorac Surg. 2008;34(4):820-5.

24. Anandaswamy TC, Rajappa GC, Krishnamachar H. Vasoplegic syndrome during Whipple procedure. J Clin Anesth. 2017;36:151-2.

25. Cao Z, Gao Y, Tao G. Vasoplegic syndrome during liver transplantation. Anesth Analg. 2009;108(6):1941-3.

26. Kohl BA, Deutschman CS. The inflammatory response to surgery and trauma. Curr Opin Crit Care. 2006;12(4):325-32.

27. Harrois A, Hamada SR, Duranteau J. Fluid resuscitation and vasopressors in severe trauma patients. Curr Opin Crit Care. 2014;20(6):632-7.

28. Lundy JB, Chung KK, Pamplin JC, Ainsworth CR, Jeng JC, Friedman BC Update on severe burn management for the intensivist. J Intensive Care Med. 2016:31(8):499-510

29. Karimgani I, Porter KA, Langevin RE, Banks PA. Prognostic factors in sterile pancreatic necrosis. Gastroenterology. 1992;103(5):1636-40.

30. Eklund A, Leppäniemi A, Kemppainen E, Pettilä V. Vasodilatory shock in severe acute pancreatitis without sepsis: is there any place for hydrocortisone treatment? Acta Anaesthesiol Scand. 2005;49(3):379-84.

31. Levick JR. An introduction to cardiovascular physiology. Abingdon: CRC Press; 2011.
32. Palmer RMJ, Ferrige AG, Moncada S. Nitric oxide release accounts for the biological activity of endothelium-derived relaxing factor. Nature. 1987;327(6122):524-6.

33. Förstermann U, Münzel T. Endothelial nitric oxide synthase in vascular disease: from marvel to menace. Circulation. 2006;113(13):1708-14.

34. Seddon MD, Chowienczyk PJ, Brett SE, Casadei B, Shah AM. Neuronal nitric oxide synthase regulates basal microvascular tone in humans in vivo. Circulation. 2008;117(15):1991-6.

35. Moncada S, Palmer RM, Higgs EA. Nitric oxide: physiology, pathophysiology, and pharmacology. Pharmacol Rev. 1991;43(2):109-42.

36. Denninger JW, Marletta MA. Guanylate cyclase and the -NO/CGMP signaling pathway. Biochimica et Biophysica Acta. 1999;1411(2-3):334-50.

37. Kimmoun A, Ducrocq N, Levy B. Mechanisms of vascular hyporesponsiveness in septic shock. Curr Vasc Pharmacol. 2013;11(2):139-49.

38. Lange M, Enkhbaatar $\mathrm{P}$, Nakano $\mathrm{Y}$, Traber DL. Role of nitric oxide in shock: the large animal perspective. Front Bioscie. 2009;14:1979-89.

39. Bakker J, Grover R, McLuckie A, Holzapfel L, Andersson J, Lodato R, Watson D, Grossman S, Donaldson J, Takala J, et al. Administration of the nitric oxide synthase inhibitor NG-methyl-L-arginine hydrochloride (546C 88 ) by intravenous infusion for up to 72 hours can promote the resolution of shock in patients with severe sepsis: results of a randomized, double-blind, placebo-controlled multicenter study (study no. 144-002). Crit Care Med. 2004:32(1):1-12.

40. Lopez A, Lorente JA, Steingrub J, Bakker J, McLuckie A, Willatts S, Brockway M, Anzueto A, Holzapfel L, Breen D, et al. Multiple-center, randomized, placebo-controlled, double-blind study of the nitric oxide synthase inhibitor 546C88: effect on survival in patients with septic shock. Crit Care Med. 2004;32(1):21-30.

41. Wang Z, Lambden S, Taylor V, Sujkovic E, Nandi M, Tomlinson J, Dyson A, McDonald N, Caddick S, Singer M, et al. Pharmacological inhibition of DDAH1 improves survival, hemodynamics and organ function in experimental septic shock. Biochem J. 2014;460:309-16.

42. Dorris SL, Peebles RS. PGI2 as a regulator of inflammatory diseases. Mediat Inflamm. 2012:2012:9.

43. Narumiya S, Sugimoto Y, Ushikubi F. Prostanoid receptors: structures, properties, and functions. Physiol Rev. 1999:79(4):1193-226.

44. Parkington HC, Coleman HA, Tare M. Prostacyclin and endotheliumdependent hyperpolarization. Pharmacol Res. 2004:49(6):509-14.

45. Endo H, Akahoshi T, Kashiwazaki S. Additive effects of IL-1 and TNF on induction of prostacyclin synthesis in human vascular endothelial cells. Biochem Biophys Res Commun. 1988;156(2):1007-14.

46. Stuart MJ, Setty Y, Walenga RW, Graeber JE, Ganley C. Effects of hyperoxia and hypoxia on vascular prostacyclin formation in vitro. Pediatrics. 1984; 74(4):548-53.

47. Riedo FX, Munford RS, Campbell WB, Reisch JS, Chien KR, Gerard RD. Deacylated lipopolysaccharide inhibits plasminogen activator inhibitor-1, prostacyclin, and prostaglandin E2 induction by lipopolysaccharide but not by tumor necrosis factor-alpha. J Immunol. 1990;144(9):3506-12.

48. Bernard GR, Wheeler AP, Russell JA, Schein R, Summer WR, Steinberg KP, Fulkerson WJ, Wright PE, Christman BW, Dupont WD, et al. The effects of ibuprofen on the physiology and survival of patients with Sepsis. N Engl J Med. 1997;336(13):912-8

49. Sellers MM, Stallone JN. Sympathy for the devil: the role of thromboxane in the regulation of vascular tone and blood pressure. Am J Phys Heart Circ Phys. 2008;294(5):H1978-86.

50. Yu Y, Ricciotti E, Scalia R, Tang SY, Grant G, Yu Z, Landesberg G, Crichton I, Wu W, Puré E, et al. Vascular COX-2 modulates blood pressure and thrombosis in mice. Sci Transl Med. 2012;4(132):132ra154

51. Ricciotti E, FitzGerald GA. Prostaglandins and inflammation. Arterioscler Thromb Vasc Biol. 2011;31(5):986-1000.

52. Yamada T, Fujino T, Yuhki K-i, Hara A, Karibe H, Takahata O, Okada Y, Xiao CY, Takayama K, Kuriyama S, et al. Thromboxane A<sub $>2</$ sub $>$ Regulates Vascular Tone via Its Inhibitory Effect on the Expression of Inducible Nitric Oxide Synthase. Circulation. 2003;108(19):2381-6.

53. Boffa J-J, Just A, Coffman TM, Arendshorst WJ. Thromboxane receptor mediates renal vasoconstriction and contributes to acute renal failure in Endotoxemic mice. J Am Soc Nephrol. 2004;15(9):2358-65.

54. Oettinger W, Peskar BA, Beger HG. Profiles of endogenous prostaglandin F2 alpha, thromboxane A2 and prostacyclin with regard to cardiovascular and organ functions in early septic shock in man. Eur Surg Res. 1987;19(2):65-77. 
55. Yanagisawa M, Kurihara H, Kimura S, Tomobe $Y$, Kobayashi M, Mitsui $Y$, Yazaki Y, Goto K, Masaki T. A novel potent vasoconstrictor peptide produced by vascular endothelial cells. Nature. 1988;332(6163):411-5.

56. Luscher TF, Barton M. Endothelins and endothelin receptor antagonists: therapeutic considerations for a novel class of cardiovascular drugs. Circulation. 2000;102(19):2434-40.

57. Hynynen MM, Khalil RA. The vascular endothelin system in hypertensionrecent patents and discoveries. Recent Pat Cardiovasc Drug Discov. 2006;1(1):95-108

58. Yeager ME, Belchenko DD, Nguyen CM, Colvin KL, IVy DD, Stenmark KR. Endothelin-1, the unfolded protein response, and persistent inflammation: role of pulmonary artery smooth muscle cells. Am J Respir Cell Mol Biol. 2012;46(1):14-22.

59. Kowalczyk A, Kleniewska P, Kolodziejczyk M, Skibska B, Goraca A. The role of Endothelin-1 and endothelin receptor antagonists in inflammatory response and Sepsis. Arch Immunol Ther Exp. 2015;63:41-52

60. Liaudet $L$, Rosenblatt-Velin N, Pacher P. Role of peroxynitrite in the cardiovascular dysfunction of septic shock. Curr Vasc Pharmacol. 2013;11(2):196-207.

61. Marik PE, Khangoora V, Rivera R, Hooper MH, Catravas J. Hydrocortisone, vitamin $C$ and thiamine for the treatment of severe Sepsis and septic shock: a retrospective before-after study. Chest. 2017;151(6):1229-38.

62. Macarthur H, Westfall TC, Riley DP, Misko TP, Salvemini D. Inactivation of catecholamines by superoxide gives new insights on the pathogenesis of septic shock. Proc Natl Acad Sci U S A. 2000;97(17):9753-8.

63. Szabo C. Hydrogen sulphide and its therapeutic potential. Nat Rev Drug Discov. 2007:6(11):917-35.

64. Li L, Bhatia M, Zhu YZ, Zhu YC, Ramnath RD, Wang Z, Anuar FB, Whiteman M, Salto-Tellez M, Moore PK. Hydrogen sulfide is a novel mediator of lipopolysaccharide-induced inflammation in the mouse. FASEB J. 2005;19(9):1196-8.

65. Koenitzer JR, Isbell TS, Patel HD, Benavides GA, Dickinson DA, Patel RP, Darley-Usmar VM, Lancaster JR Jr, Doeller JE, Kraus DW. Hydrogen sulfide mediates vasoactivity in an O2-dependent manner. Am J Phys Heart Circ Phys. 2007;292(4):H1953-60.

66. Dorman DC, Moulin FJ, McManus BE, Mahle KC, James RA, Struve MF. Cytochrome oxidase inhibition induced by acute hydrogen sulfide inhalation: correlation with tissue sulfide concentrations in the rat brain, liver, lung, and nasal epithelium. Toxicol Sci. 2002;65(1):18-25.

67. Laggner H, Hermann M, Esterbauer H, Muellner MK, Exner M, Gmeiner BM, Kapiotis $\mathrm{S}$. The novel gaseous vasorelaxant hydrogen sulfide inhibits angiotensin-converting enzyme activity of endothelial cells. J Hypertens. 2007:25(10):2100-4.

68. Ali MY, Ping CY, Mok YY, Ling L, Whiteman M, Bhatia M, Moore PK. Regulation of vascular nitric oxide in vitro and in vivo; a new role for endogenous hydrogen sulphide? Br J Pharmacol. 2006;149(6):625-34.

69. Hosoki R, Matsuki N, Kimura $\mathrm{H}$. The possible role of hydrogen sulfide as an endogenous smooth muscle relaxant in synergy with nitric oxide. Biochem Biophys Res Commun. 1997;237(3):527-31.

70. Blackstone $E$, Roth MB. Suspended animation-like state protects mice from lethal hypoxia. Shock. 2007;27(4):370-2.

71. Morrison ML, Blackwood JE, Lockett SL, Iwata A, Winn RK, Roth MB. Surviving blood loss using hydrogen sulfide. J Trauma. 2008;65(1):183-8.

72. Sodha NR, Clements RT, Feng J, Liu Y, Bianchi C, Horvath EM, Szabo C, Sellke FW. The effects of therapeutic sulfide on myocardial apoptosis in response to ischemia-reperfusion injury. Eur J Cardiothorac Surg. 2008;33(5):906-13.

73. Landry DW, Oliver JA. The ATP-sensitive K+ channel mediates hypotension in endotoxemia and hypoxic lactic acidosis in dog. J Clin Invest. 1992;89(6):2071-4

74. Davies NW. Modulation of ATP-sensitive K+ channels in skeletal muscle by intracellular protons. Nature. 1990;343(6256):375-7.

75. Keung EC, Li Q. Lactate activates ATP-sensitive potassium channels in Guinea pig ventricular myocytes. J Clin Invest. 1991;88(5):1772-7.

76. Vanelli G, Hussain SN, Dimori M, Aguggini G. Cardiovascular responses to glibenclamide during endotoxaemia in the pig. Vet Res Commun. 1997;21(3):187-200.

77. Vanelli G, Hussain SN, Aguggini G. Glibenclamide, a blocker of ATP-sensitive potassium channels, reverses endotoxin-induced hypotension in pig. Exp Physiol. 1995;80(1):167-70.

78. Warrillow S, Egi M, Bellomo R. Randomized, double-blind, placebocontrolled crossover pilot study of a potassium channel blocker in patients with septic shock. Crit Care Med. 2006;34(4):980-5.

79. Buckley JF, Singer M, Clapp LH. Role of KATP channels in sepsis. CardiovasC Res. 2006;72(2):220-30.
80. McMillan M, Chernow B, Roth BL. Hepatic alpha 1-adrenergic receptor alteration in a rat model of chronic sepsis. Circ Shock. 1986;19(2):185-93.

81. Roth BL, Spitzer JA. Altered hepatic vasopressin and alpha 1-adrenergic receptors after chronic endotoxin infusion. Am J Phys. 1987;252(5 Pt 1):E699-702.

82. Hwang TL, Lau YT, Huang SF, Chen MF, Liu MS. Changes of alpha 1adrenergic receptors in human liver during intraabdominal sepsis. Hepatology. 1994;20(3):638-42.

83. Beishuizen A, Thijs LG, Vermes I. Patterns of corticosteroid-binding globulin and the free cortisol index during septic shock and multitrauma. Intensive Care Med. 2001;27(10):1584-91.

84. Hadoke PWF, lqbal J, Walker BR. Therapeutic manipulation of glucocorticoid metabolism in cardiovascular disease. Br J Pharmacol. 2009;156(5):689-712.

85. Prigent H, Maxime V, Annane D. Clinical review: Corticotherapy in sepsis. Crit Care. 2004;8(2):122-9.

86. Hadoke PW, Macdonald L, Logie JJ, Small GR, Dover AR, Walker BR. Intravascular glucocorticoid metabolism as a modulator of vascular structure and function. Cell Mol Life Sci. 2006;63(5):565-78.

87. Lowenberg M, Stahn C, Hommes DW, Buttgereit F. Novel insights into mechanisms of glucocorticoid action and the development of new glucocorticoid receptor ligands. Steroids. 2008;73(9-10):1025-9.

88. De Bosscher K, Haegeman G. Minireview: latest perspectives on Antiinflammatory actions of glucocorticoids. Mol Endocrinol. 2009:23(3):281-91.

89. Schroeder $S$, Wichers $M$, Klingmuller D, Hofer M, Lehmann LE, von Spiegel T, Hering R, Putensen C, Hoeft A, Stuber F. The hypothalamic-pituitary-adrenal axis of patients with severe sepsis: altered response to corticotropinreleasing hormone. Crit Care Med. 2001:29(2):310-6.

90. Marik PE, Zaloga GP. Adrenal insufficiency during septic shock. Crit Care Med. 2003:31(1):141-5.

91. Soni A, Pepper GM, Wyrwinski PM, Ramirez NE, Simon R, Pina T, Gruenspan $\mathrm{H}$, Vaca CE. Adrenal insufficiency occurring during septic shock: incidence, outcome, and relationship to peripheral cytokine levels. Am J Med. 1995; 98(3):266-71.

92. Annane $D$, Sébille $V$, Charpentier $C$, et al. Effect of treatment with low doses of hydrocortisone and fludrocortisone on mortality in patients with septic shock. JAMA. 2002;288(7):862-71.

93. Annane D, Sebille $V$, Bellissant E. Effect of low doses of corticosteroids in septic shock patients with or without early acute respiratory distress syndrome. Crit Care Med. 2006;34(1):22-30.

94. Sprung CL, Annane D, Keh D, Moreno R, Singer M, Freivogel K, Weiss YG, Benbenishty J, Kalenka A, Forst $H$, et al. Hydrocortisone therapy for patients with septic shock. N Engl J Med. 2008;358(2):111-24.

95. Landry DW, Levin HR, Gallant EM, Ashton RC Jr, Seo S, D'Alessandro D, Oz MC, Oliver JA. Vasopressin deficiency contributes to the vasodilation of septic shock. Circulation. 1997:95(5):1122-5.

96. Barrett LK, Singer M, Clapp LH. Vasopressin: mechanisms of action on the vasculature in health and in septic shock. Crit Care Med. 2007:35(1):33-40.

97. Khanna A, English SW, Wang XS, Ham K, Tumlin J, Szerlip H, Busse LW, Altaweel L, Albertson TE, Mackey C. Angiotensin II for the treatment of vasodilatory shock. N Engl J Med. 2017;377:419-30. 